\title{
Somatostatin and cognitive function in neurodegenerative disorders
}

Gábor Tuboly ${ }^{1}$, László Vécsei ${ }^{1,2}$.

\begin{abstract}
During the past 40 years, somatostatin (SST) has been a subject of intensive research. Apart from its substantial role in the neuroendocrine system, due to its dense localization in various areas in the brain, its functions as a neuromodulator have also been thoroughly investigated. Increasing evidence suggests that SST plays a crucial role in memory and cognition. Synthetic forms, biologically active peptide sequences, SST receptor agonists and SST depleting agents have been applied in animal models and in human studies of a number of neuropsychiatric disorders. The translation of experimental data into clinical use could provide novel therapies in neurodegenerative disorders involving cognitive dysfunctions. However in view of the controversial data reported concerning the different roles of the SST receptor subtypes, and the lack of SST analogues that are able to cross diffusion barriers and act selectively at these receptor subtypes, broader clinical use of SST analogues as cognitive enhancers is limited. This review covers the whole range of available experimental results relating to the behavioural effects of SST, and highlights the potential for further investigations.
\end{abstract}

Keywords: Alzheimer's disease, animal models, cognition, Huntington's disease, learning, memory, Parkinson's disease, somatostatin.

\footnotetext{
Affiliations:

1: Department of Neurology, Faculty of Medicine, Albert Szent-Györgyi Clinical Centre, University of Szeged, Semmelweis u. 6, Szeged 6725, Hungary.

e-mail: vecsei.laszlo@med.u-szeged.hu

2: Research Group of the Hungarian Academy of Sciences, University of Szeged, Szeged, Hungary.
} 


\section{Introduction}

Somatostatin (SST) also known as somatotropin release-inhibiting factor (SRIF) was discovered in 1972 by Guillemin at al., who were attempting to purify and characterize growth hormone $(\mathrm{GH})$-releasing hormone $(\mathrm{GHRH})$ from the ovine hypothalamus, but instead discovered an inhibitor of GH release [1]. Since its discovery, SST has been identified throughout the central nervous system (CNS), in the endocrine tissues and in the gastrointestinal tract.

There are two native, biologically active forms of SST, the 14 amino acidcontaining form (SST-14) and its N-terminally extended precursor SST-28 (Fig. 1) [2]. Like other protein hormones, SST is produced by enzymatic cleavage from a larger inactive precursor molecule, prepro-SST, a polypeptide consisting of 116 amino acids which yields the active polypeptides (Fig. 2) [3]. Processing of prepro-SST to generate the two bioactive forms primarily occurs at the C-terminal end. SST-14 is generated by dibasic cleavage of an Arg-Lys residue, whereas endoproteolysis of a monobasic Arg site furnishes SST-28 [4,5].

SST is produced in high density in cells throughout the CNS, the peripheral nervous system, the endocrine pancreas and the gut, in addition to the thyroid, adrenals, submandibular glands, kidney, prostate, placenta, blood vessel walls, and immune cells [6-15]. In view of its coexistence in neurones with classical neurotransmitters, its release properties and its capacity to modulate synaptic transmission and neuronal activity, SST can be regarded as a neuromodulatory agent [16]. Lepousez et al. recently demonstrated that SST-immunoreactive interneurones interact directly with mitral cell dendrites, with the participation of dendrodendritic reciprocal synapses. This provides an anatomical basis for a neuromodulatory role of the peptide on the granule-mitral cell dendritic interactions that are fundamental to olfactory processing [17,18].

Somatostatinergic neurones occur in high densities throughout the CNS and give rise to an extensive network of SST-containing fibres and axon terminals in numerous brain regions, including the cerebral cortex, hippocampus, amygdala, hypothalamus, brainstem and spinal cord [14]. From the results of specific receptor binding and genetically modified animal models, the anatomy and function of the somatostatinergic 
pathways have been revealed (for a review see Viollet et al., 2008) [16]. However, the functional role and development of these pathways are still subjects of extensive examination. In a recent review, Epelbaum et al. emphasized the role of the hippocampal somatostatinergic pathways in memory, cognition and emotions [19].

There is increasing evidence that SST contributes to the organization of the CNS. The early appearance of SST receptors (sst-s) has been demonstrated in the rat brain. Gonzalez et al. detected high levels of SST-binding sites in the brain of 15-day-old foetuses, and autoradiographic studies revealed marked differences in the distribution of sst-s during ontogenesis. In the cortex, the cortical plate and the subplate zone appeared to contain high densities of binding sites until birth. After postnatal day 4, this laminar distribution of binding sites in the cortex disappeared and a homogeneous distribution was observed in almost all cortical layers [20]. Sirviö et al. measured SST-like immunoreactivity (SLI) in the brains of rats aged 1,8 and 18 months, and found an overall progressive reduction in cortical SST binding [21]. In the cerebellum, these effects have been reported to be much more dramatic. In the neonatal rat cerebellum, the external granule cell layer, a germinal matrix containing interneurone precursors, contains a high density of sst-s (predominantly sst2a) receptors. In adult rats, the cerebellum is devoid of sst-s [22]. These results suggested that SST might control the migratory behavior of immature neurones [23], primarily through mediation by the sst2A subtype [24,25]. Le Verche and colleagues later confirmed these hypotheses in in vitro and in vivo experiments [26].

The goal of the present review is to survey knowledge relating to the effects of SST on cognitive functions and neurologic diseases involving impaired cognition, i.e. Alzheimer's disease (AD), Huntington's disease (HD), and Parkinson's disease (PD) and amyotrophic lateral sclerosis (ALS).

\section{Somatostatin receptors}

The cloning and functional characterization of the sst subtypes that bind SST-14 and SST-28 with high affinity has firmly established that the physiological actions of SST are mediated by a family of sst-s, believed to be glycoproteins. The experimental 
indication that the carbohydrate component of the sst-s may be involved in promoting high-affinity ligand binding [27,28] suggested that there may be several different subtypes of sst-s [28]. The use of iodinated somatostatinergic ligands identified two pharmacologically distinct binding sites in the brain. Six sst subtypes (sst1, sst2A, sst2B, sst3, sst4 and sst5), belonging in the G-protein-coupled receptor family were cloned and divided into two subfamilies on the basis of structural and operational features: sst2, sst3 and sst5 in the SRIF-1 subfamily, and sst1 and sst4 in the SRIF-2 subfamily, distinguished by the high affinity of cyclic peptides such as octreotide (SMS-201-995), seglitide (MK-678) and lanreotide (BIM-23014) for the SRIF-1 group [29-31]. CórdobaChacón et al. recently identified and characterized four novel truncated sst5 variants in rodents [32], displaying different numbers of transmembrane domains. Three of these were obtained from mice, and one from the rat hypothalamus and pituitary.

Comparisons of the sequences of the receptor subtypes from different species indicate that the sequence of sstl is the most highly conserved, with $97 \%$ identity between the human and rodent proteins, whereas the sequence of sst5 is the most divergent, with only $81 \%$ identity between the human and rat sequences. The identity between human and rat sst2, sst3 and sst 4 is 92,86 and $89 \%$, respectively. The amino acid sequence differences within a receptor subtype are located primarily in the regions of the extracellular amino domain and intracellular carboxy termini, with the sequences of the membrane-spanning alpha-helical segments and intracellular connecting loops being more highly conserved [33]. The genes coding for sst1, sst3, sst4 and sst5 are intronless, whereas in rodents the gene for sst 2 contains three introns, which result in the generation of two receptor protein variants: the unspliced sst $2 \mathrm{~A}$, and sst $2 \mathrm{~B}$, which is spliced in the carboxy terminal part of the gene, and differs from sst2A in the length of its carboxy tail [31]. The mRNAs for the sst subtypes, widely expressed at different levels in human and rodent tissues, have distinct, but overlapping patterns of expression. All six subtypes are expressed in the CNS; sst1 can be found in the small intestine, stomach and lung; sst2 in the kidney, pituitary and adrenal gland; sst3 in the pancreatic islets; and sst5 in the pituitary as well [33].

The sst-s are linked via guanine nucleotide binding proteins (inhibitory G-protein $\left[\mathrm{G}_{\mathrm{i}}\right]$ and brain-derived G-protein $\left[\mathrm{G}_{\mathrm{o}}\right]$ ) to multiple cellular effector systems. They mediate 
the inhibition of adenylyl cyclase activity, leading to a reduction of the conductance of voltage-dependent $\mathrm{Ca}^{2+}$ channels, and the stimulation of different $\mathrm{K}^{+}$channels [34-40]. They additionally mediate the stimulation of tyrosine phosphatase activity, the reduction of cell proliferation and the inhibition of a $\mathrm{Na}^{+} / \mathrm{H}^{+}$exchanger (NHE1) [41].

As regards SST, it may act on a distant "third" synaptic component, modulating glutamatergic or GABAergic transmission. Apart from this neuromodulatory effect, it can evoke a response on its own postsynaptic element (a neurotransmitter-like effect). In both modes of action, the effects of SST are slower and longer-lasting relative to those of classical neurotransmitters. The neuromodulatory effects of SST are mostly presynaptic. SST inhibits glutamate release via sst1 [42], sst2 [43] or sst5 [38], depending on the anatomical structure [44]. SST exhibits long-lasting effects on glutamatergic synapses, either depressing long-term potentiation in the dentate gyrus/lateral perforant path [38] or enhancing it in the dentate gyrus/medial perforant path [45]. One study reported an intracellular $\mathrm{Ca}^{2+}$-dependent modulation of AMPA currents postsynaptically, mediated by sst 2 activation in the hypothalamus [46]. Interestingly, in sst2 knock-out (KO) mice, the glutamatergic responses were increased in the hippocampal slices [47], suggesting that SST exerts an inhibitory tone on glutamatergic transmission through sst2 activation [48]. However, the activation of sst4, selectively expressed in the hippocampal CA1, increased the hippocampal glutamatergic responses, an effect inhibited by the activation of sst2, suggesting the possible functional interaction of these subtypes [49]. Furthermore, SST has been found to inhibit GABA release presynaptically $[42,50]$.

SST plays a key role in the control of pituitary hormone release, most notably that of $\mathrm{GH}$, but also those of thyroid stimulating hormone and, in some cases, adrenocorticotropic hormone and prolactin [51]. Besides this direct control of GH secretion at the pituitary level, mediated through the activation of sst 2 and sst5, some studies have pointed to an intrahypothalamic control of $\mathrm{GH}$, involving primarily sst1 and sst2. Thus, SST would inhibit GHRH neurones and thus GH secretion on one hand, and on the other hand it would exert a negative feedback on its own release, thereby resulting in a stimulation of GHRH and GH release [44,52,53]. The diversity of the actions of SST suggests that it should have a number of other potential therapeutic uses as well. The localization of specific sst subtypes in the previously described regions of the brain 
implicated in locomotor activity, sensory perception, learning and memory suggest that non-peptide SST analogues that can cross the blood-brain barrier may have potential therapeutic applications in neuropsychiatric disorders $[33,51,54,55]$.

\section{Animal studies}

The first evidence of a behavioural effect of SST was the observation of a transient tranquillizing effect of a large dose administered intravenously to monkeys (Table 1) [56]. Several later studies on rodents indicated a role for the peptide in the control of locomotor activity, and also in learning and memory processes. The intracerebroventricular (i.c.v.) injection of SST induced marked behavioural excitation in rats associated with a reduction in slow-wave and rapid eye movement sleep [57]. Experiments by our group two decades ago, likewise revealed that i.c.v. administration of the peptide influenced self-stimulation, inhibited the extinction of active avoidance behaviour, provoked antiamnesic effects and increased the locomotor activity [58-64]. In more recent studies our group has considered the hypothesis that SST may act on memory consolidation or retention processes [65]. I.c.v. injections of SST have been demonstrated to improve the performance in passive avoidance and shuttle box learning in rats. It produced barrel rotation in a dose-related manner and decreased the rearing activity. On the other hand, subcutaneously administered cysteamine and pantethine (SST-depleting substances) diminished the avoidance latency of the animals in a doserelated manner in passive and active avoidance tests. They markedly reduced several manifestations of open-field behaviours, such as locomotion, rearing, grooming and defecation, and attenuation of SST-induced barrel rotation [66-68]. Since the late 80's various other groups have also established that, in both active and passive training protocols, extinction of the avoidance response is facilitated after appropriate systemic cysteamine injection [69-75], and SST depletion results in learning and memory deficits, revealed by an impaired performance in shuttle box learning, or in the morris water Maze in rats [76-78]. As concerns the effects of i.c.v. or intrahippocampal cysteamine treatment, Guillou et al. found that, while it impaired spatial learning, cysteamine was also capable of accelerating the acquisition of a bar-pressing task by increasing the 
retention of information from one session to another in mice. Their results suggested that depending on the type of learning, bidirectional hippocampal function regulatory mechanisms involving both SST and adenyl cyclases may exist [79]. Opposite regulation of the hippocampal system may occur during different kinds of learning, and their modulation by pharmacological agents can produce opposite effects on the acquisition of different tasks according to their synergistic or antagonistic action with the effects of learning alone [80].

On the other hand, SST and its effective agonists exert positive effects in most cognitive tests. I.c.v. administration of SST or its analogue SMS-201995 (selective for sst2, sst3 and sst5) reversed cysteamine-induced impairment in active and passive avoidance protocols [71,81]. Romanova et al demonstrated that decorticated rats performed significantly better after i.c.v. injections of SST, in passive avoidance tests [82]. Recent studies have focused on the effects of centrally and peripherally applied sst agonists on motor and cognitive functions in animal models, suggesting a viable therapy for the treatment of $\mathrm{AD}$ and other forms of cognitive impairment. Matsuoka et al. compared the anti-amnesic and cognitive effects of FR121196 (N-[4-acetyl-1piperazinyl]-4-fluorobenzenesulfonamide) and SST. FR121196 is a putative cognitive enhancer substance, that possibly acts via dopaminergic and/or cholinergic mechanisms. They found that, while i.c.v. administered SST significantly ameliorated the memory impairments induced both by cysteamine and by scopolamine and nucleus basalis magnocellularis (NBM) lesioning, FR121196 ameliorated only those produced by scopolamine and NBM lesioning, and not those in the case of cysteamine [81].

The same group evaluated the cognitive enhancing actions of FK960 ( N-[4acetyl-1-piperazinyl]-p-fluorobenzamide monohydrate; a SST-releasing agent) with NBM or fimbria fornix lesioning after cysteamine or scopolamine treatment in aged rats and after cysteamine administration in the rhesus monkey. FK960 improved visual recognition in the monkey, and ameliorated all the memory impairments in rats except those induced by cysteamine or fimbria fornix lesion. However, the effects of FK960 on scopolamine-induced memory impairment were abolished by cysteamine, suggesting that FK960 ameliorates the cognitive dysfunction through an activation of the SST-ergicserotonergic link $[77,83]$. Tokita et al. reported similar results after intraperitoneal 
injections of FK960 and FK962 (N-[1-acetylpiperidin-4-yl]-4-fluorobenzamide; another SST-releasing agent), and found that these compounds were able to ameliorate cognitive dysfunction in rat models $[84,85]$.

Controversial results have been published, as regards the startle response and prepulse inhibition (PPI; an important test for sensory gating which is impaired in several cognitive diseases). Fendt et al. indicated that the SST-ergic projection from the central grey to the caudal pontine reticular nucleus $(\mathrm{PnC})$ is important for modulation of the fearpotentiated startle response. When octreotide, a synthetic octapeptide, with high affinity to the sst2, sst3, and sst5, but very low affinity for sst1 and sst4 [86], was injected into the PnC, it blocked fear potentiation of the startle response, whereas it had no effect on the tone-evoked activity of PnC neurones [74]. Kungel et al. found that chronic cysteamine treatment impaired the development of the acoustic startle response in rats, while Feifel and Minor showed that cysteamine reversed the decreases in PPI induced by systemic injections of amphetamine, but had no effect on the amplitude of the acoustic startle reflex itself $[73,75]$. In a recent investigation Semenova et al. established that the administration of SST-28 (10 $\mu$ g i.c.v) significantly decreased PPI with no effect on the amplitude of the acoustic startle response or startle response habituation [87]. Administration of the selective sst1 antagonist SRA-880 tended to reverse the SSTinduced deficits in PPI. They assumed that increased SST transmission may be one of the neurochemical mechanisms underlying anhedonia, one of the negative symptoms of schizophrenia, and the sensorimotor gating deficits associated with cognitive impairments in schizophrenia patients.

Gastambide et al. tested the effects of selective sst agonists on both short- and long-term memory in mouse models, demostrating that the intrahippocampal injection of SST-14 decreased place learning and memory, this deterioriation mainly being mediated by sst4 receptors [88].

(For a brief summary see table 1.).

Null mutant mice lacking SST also displayed significant impairments in motor learning [89]. Interestingly, sst2 KO mice exhibited a specific facilitation of learning in a hippocampal-dependent spatial discrimination task, while the working memory was not modified in an operant learning protocol [90-92]. However, SST KO animals did not 
indicate major learning and memory defects, as opposed to mice overexpressing cortistatin, a SST-related peptide [91,93]. A recent study revealing the effects of sst3 in object recognition, object information and synaptic plasticity emphasized that neuronal cilia detecting SST (via sst3) are critical for object memory [94]. When sst2 or sst3 or sst4 receptor KO mice participated in object recognition tests, it was found that the lack of sst3 was associated with an impaired degree of object recognition but had no effect on the memory of object location. However, as in all studies involving the use of genetically engineered mouse mutants with the constitutively arrested expression of a certain gene of interest, the data obtained must be interpreted with caution. Both compensatory processes and differences in the genetic background of the flanking regions of the mutation site may contribute to the phenotype observed [95].

\section{Neurological diseases and somatostatin}

SST has been implicated in a variety of neurological diseases. Changes in SST and its receptors have long been associated with dementia, epilepsy and major affective disorders [51]. A decreased level of SST in the cerebrospinal fluid (CSF) has been observed in patients with impaired cognition, such as schizophrenia, AD, PD, essential tremor, drug refractory epilepsy and active multiple sclerosis [96].

\section{Alzheimer's disease}

$\mathrm{AD}$ is an irreversible neurodegenerative disorder that predominantly affects individuals over age the age of 65 . It is characterized clinically by progressive dementia, and histopathologically by the presence of extracellular deposits of amyloid fibrils in the core of senile plaques, intracellular neurofibrillar tangles and neuronal cell loss $[97,98]$. One of the principal components of senile plaques, amyloid $\beta$-peptide $(\mathrm{A} \beta)$, is considered to be involved in the pathogenesis of $\mathrm{AD}[99,100]$. $\mathrm{A} \beta$ is formed from the amyloid precursor protein by sequential enzymatic processing. The accumulation of $A \beta$ has been 
associated with progressive neuronal death, cognitive deficits and neuropsychiatric disorders such as agitation, apathy and increased anxiety [101-104].

Among the different neuropeptides whose levels are significantly altered in patients with AD, SST is reported to be the most consistently reduced, both in the brain and in the CSF [105-112]. Immunohistochemical analyses of human control and AD brains have revealed a significant reduction $(>70 \%)$ in the number of SSTimmunoreactive neurones in the AD frontal cortex [113], which would account for the deficit in SST concentration previously reported in this brain area $[105,114]$. In the hippocampus, substantial early losses of SST-immunopositive neurones and SST mRNA were detected in a transgenic mouse model of $\mathrm{AD}$, in the absence of changes in other neuronal markers of GABAergic, glutamatergic and cholinergic systems or in the principal cell number [115]. Furthermore, a linear correlation was observed between the SST deficiency and the A $\beta$ content. SST seems to bring about a specific increase in the activity of neprilysin (an enzyme implicated in the catabolism of $A \beta$ ), thereby promoting the degradation of $A ß 42$, presumed to be the main pathogenetic factor in the disease [116]. In view of these findings, SST could constitute an important biomarker via which to assess the efficacy of potential early AD treatment [115].

In animal studies, the continuous i.c.v. infusion of $A \beta 1-40$ or $A \beta 25-35$ for 14 days resulted in significant reductions in SLI content in the rat hippocampus, frontoparietal cortex and temporal cortex [117-120], which parallels the reduction seen in postmortem brains of patients with $\mathrm{AD}$ [105]. The treatment of such rats with IGF-1 [119] or estradiol [121] partially restored the SST parameters affected after A $\beta$ infusion. These findings suggest that the accumulation of $A \beta$ contributes, at least partly, to the well-documented deficits in SLI content throughout the AD brain.

There are data indicating that, besides SST deficiency, abnormalities at the level of the sst-s, are also present in the AD brain [122], though another study found no difference in sst density [123]. More recent studies succeeded in unravelling the specific sst subtypes affected in AD. The subtype-selective alterations in sst protein expression in $\mathrm{AD}$ cortical regions are providing an emerging picture of a central role not only of SST, but also of the sst subtypes in the pathophysiology of AD. Nevertheless there is some controversy in the results that have been published. Krantic et al. described a reduced 
sst1 binding capacity in the frontal and temporal cortices in $\mathrm{AD}$, while Kumar detected marked reductions in the neuronal expression of sst 4 and sst5 and a modest decrease in sst2-like immunoreactivity without any changes in the sst1-immunoreactive neurones in the frontal cortex of AD patients [113,124].

\section{Huntington's disease}

HD is an autosomal dominant hereditary disorder caused by an expanded polyglutamine tract in the protein huntingtin [125]. The onset of HD usually occurs in mid-life and progresses to death over 15-20 years. The disorder is characterized by motor, cognitive and psychiatric symptoms. The pathological abnormalities seem to be restricted to the CNS, with preferential vulnerability in the caudate, putamen and deep layers of the cerebral cortex [126]. Similarly to the cognitive deficits observed in human patients, animal models have revealed that a cognitive dysfunction may be present before any motor or behavioural symptom [127-130].

Decreased concentrations of a number of neurotransmitters and neuropeptides have been reported in the basal ganglia in HD. SST levels were determined in the CSF of patients with $\mathrm{HD}$, in first generation relatives of choreic patients and in neurological control patients [131]. The SST levels were markedly decreased both in the affected patients and in the symptom-free offspring. In an early study, Aronin et al. measured the concentrations of several peptide neurotransmitters in the basal ganglia of patients with HD. The levels of radioimmunoassayable SST were reported to be increased in extracts of the caudate, putamen, and external and internal globus pallidus in HD [132], a finding corroborated by studies on postmortem brain samples and SLI in healthy controls versus patients with Huntington chorea [133-135]. Marshall and Landis explained this increase in terms of the elevated SLI in the local circuit neurones, whereas the SSTimmunoreactive striatal neurones appeared to degenerate in proportion to the loss of striatal tissue, in contrast with an increase in the density of immunostained varicose fibres. In comparison, the pattern and amount of fibre staining in the substantia nigra appeared virtually unchanged from that seen in the normal brain [136]. In animal models of HD, where striatal lesions are commonly produced by the administration of kainic acid 
[137] or the NMDA receptor agonist quinolinic acid, a similar pattern of neuronal degeneration and significant elevations in SST concentrations were observed, due to the relative sparing of a small population of medium-sized, aspiny neurones containing SST and neuropeptide $\mathrm{Y}$ in the markedly neurone-depleted striatum [138-140]. Examinations of the involvement of the sst-s in HD revealed marked reductions in the density of SST binding sites in the caudate and putamen of all patients with HD, but no alterations in the nucleus accumbens or in the ventral aspects of the anterior putamen [141]. As regards the effects of cysteamine, one study indicated that the maximum tolerated dosage administered for 2 weeks produced no consistent change in the extrapyramidal or dementia scores, and the SST concentrations in the plasma or CSF were not significantly altered [142], while another study revealed that cysteamine treatment might prevent neuronal loss in the YAC128 mouse model of $\mathrm{HD}$, but was unable to reverse the neuronal dysfunction [143].

\section{Parkinson's disease}

PD is a progressive degenerative disorder of the CNS, characterized by degeneration and loss of the dopamine-containing cells of the nigrostriatal system. Levodopa treatment has been accepted as the primary treatment of PD for more than 30 years. Dupont et al. established that the SST concentrations are irreversibly low in PD patients [144]. Epelbaum et al. measured SST levels by radioimmunoassay in several regions of the cerebral cortex (frontal, entorhinal, cingulate, temporal and occipital) and also in the caudate nucleus and hypothalamus, and observed significant correlations between the decreased SST levels in the frontal cortex, the hippocampus and the entorhinal cortex and the cognitive deficit in patients with PD. In the hippocampus, significant correlations were found with both the age at onset and the duration of the disease [145]. In several studies, measurements of the concentrations of SLI in patients with extrapyramidal motor diseases, or in postmortem brain tissues revealed that the SST levels in PD patients correlated with the degree of akinesia, rigidity and autonomic disturbances, and that the AD-like dementia that occurs these patients is associated with reduced concentrations of SST in the CSF or the cortex [146-148]. In these studies, the level of SLI was found to be 
significantly lower in PD patients than in normal or senile controls without Parkinson's syndrome, and the extent of the reduction proved to be related to the progression of the disease. SST mRNA quantitation revealed a significant increase in the medial medullary lamina of the globus pallidus in PD relative to the controls, suggesting a specific modification of basal ganglia SS-ergic pathways in PD [149,150]. However, conflicting evidence has also been published, the results pointing either to a SLI elevation in the CSF [151] or to no changes in SLI post mortem in the cerebral cortex [152,153] or in cortical neurosurgical biopsies [154], suggesting that involvement of the SST-ergic system may not be a primary and consistent neurochemical feature of dementia [155], or at least it may be less significant than in AD dementia [156]. Conversely, monitoring of the levels of SST in the serum or brain samples has been used in the animal models, or during the treatment of the disease $[157,158]$. Since the late 1970's various approaches have been made to apply SST in extrapyramidal disorders and PD. SST, however, did not induce any improvement or deterioration of the symptoms, signs or EEG abnormalities in these patients $[159,160]$.

\section{Amyotrophic lateral sclerosis}

ALS, a progressive degenerative disease of the CNS is nevertheless generally considered to be a paradigm of a pure motor neurone disorder; the possible occurrence of a cognitive impairment in patients affected by ALS is recognized. A cognitive or behavioural impairment is reported in $10-50 \%$ of these patients [161]. In the largest study on patients with an original diagnosis of ALS, the dementia presented with behavioural dysfunctions in 15/41 patients, and with language dysfunctions in 26/41 [162]. Dementia in ALS may be a consequence of either frontotemporal lobar degeneration or co-existing AD [163]. The neuropathological data point to frontotemporal atrophy in ALS patients with a cognitive impairment [164]. However cognitive dysfunctions can not be exclusively explained in terms of these changes; the subcortical structures such as the amygdala and extrapyramidal sites like the globus pallidus, thalamus, and substantia nigra have been found to be involved in this disease $[165,166]$. Katagiri et al. in an earlier 
study examined levels of neuropeptides in spinal cord sections and in Onuf's nucleus. There was no significant difference between the ALS and control cases as concerns the peptide-immunoreactive fibres segments in the spinal cord or in Onuf's nucleus [167]. As regards SLI in the CSF, no change was found between ALS patients and normal subjects [168]. Nieto-Gonzalez et al. found a decreased density of parvalbumin- and SST-positive inhibitory interneurones and reduced vesicular GABA transporter immunoreactivity in the neuropil of the wobbler mouse, an animal model of ALS. Since ALS patients demonstrate cortical hyperexcitability, there is a possibility that alterations in the inhibitory GABA-ergic system might explain this dysfunction in wobbler mice [169].

\section{Therapeutic strategies - clinical applications}

The wide distribution of SST systems throughout nearly all brain regions suggests that they play significant roles in brain functioning [16]. Taken together, the experimental data that have been accumulated during the past 40 years have proved the localization of specific sst subtypes in regions of the brain implicated in locomotor activity, sensory perception, learning and memory, and suggest that SST plays a substantial role in memory and cognition. In their recent review, Epelbaum et al. concluded that SST deficit is a generalized marker for many brain disorders associated with cognitive impairments, and therefore relates to the pathophysiology of cognitive deficits in general rather than to the aetiology of a specific neuropathology [19]. There is general agreement that a low SST level or sst impairment can contribute to $\mathrm{AD}$, but the results relating to the signficance of this system in the other three neurologic diseases are inconsistent. Accordingly further studies are required to clarify the role of this system in other neurologic diseases that involve memory dysfunctions. Since the discovery of decreased SST concentrations in the brain of AD patients, which were found to correlate with the dementia score, various attempts have been made to increment or even substitute anticholinergic therapy. However, broadening of the clinical uses of SST analogues is limited by the paucity of SST analogues that are selective at the different receptor subtypes, and the lack of SST drugs that are stable and able to cross diffusion barriers. Recentlydeveloped non-peptide SST analogues that can traverse the blood-brain barrier may be of 
considerable potential in the treatment of cognitive impairments. Further studies can help to reveal the effects of different sst-specific ligands on cognitive functions. Investigations of combinations of SST with ligands acting on other receptors may also be a promising possibility. In conclusion, knowledge concerning the role of SST system is currently incomplete and further studies are required to solve the controversies that have emerged between the various experimental and clinical results.

\section{Conflict of Interest}

The author(s) confirm that this article content has no conflicts of interest.

\section{Acknowledgements}

The present study was supported by TÁMOP-4.2.1/B-09/1/KONV-2010-0005, Hungarian Academy of Sciences and University of Szeged.

Table 1. Summary of the behavioural effects observed on modification of the somatostatin system in animal studies.

Figure 1. Amino acid sequences of somatatostatin-28 and somatatostatin-14.

Figure 2. Schematic preprosomatostatin and pro-somatostatin amino acid chain sequences related to somatatostatin-28 and somatatostatin-14.

\section{References}

[1] Brazeau, P.; Vale, W.; Burgus, R.; Ling, N.; Butcher, M.; Rivier, J.; Guillemin, R. Hypothalamic polypeptide that inhibits the secretion of immunoreactive pituitary growth hormone. Science, 1973, 179(4068), 77-79. 
[2] Pradayrol, L.; Jörnvall, H.; Mutt, V.; Ribet, A. N-terminally extended somatostatin: The primary structure of somatostatin-28. FEBS Letters, 1980, 109(1), 55-58.

[3] Goodman, R. H.; Lund, P. K.; Jacobs, J. W.; Habener, J. F. Pre-prosomatostatins. Products of cell-free translations of messenger RNAs from anglerfish islets. J. Biol. Chem., 1980, 255(14), 6549-6552.

[4] Patel, Y. C.; O'Neil, W. Peptides derived from cleavage of prosomatostatin at carboxyl- and amino-terminal segments. Characterization of tissue and secreted forms in the rat. J. Biol. Chem., 1988, 263(2), 745-751.

[5] Bersani, M.; Thim, L.; Baldissera, F. G.; Holst, J. J. Prosomatostatin 1-64 is a major product of somatostatin gene expression in pancreas and gut. J. Biol. Chem., 1989, 264(18), 10633-10636.

[6] Arimura, A.; Sato, H.; Dupont, A.; Nishi, N.; Schally, A. V. Somatostatin: abundance of immunoreactive hormone in rat stomach and pancreas. Science, 1975, 189(4207), 1007-1009.

[7] Dubois, M. P. Immunoreactive somatostatin is present in discrete cells of the endocrine pancreas. Proc. Natl. Acad. Sci. U. S. A, 1975, 72(4), 1340-1343.

[8] Hokfelt, T.; Johansson, O.; Efendic, S.; Luft, R.; Arimura, A. Are there somatostatincontaining nerves in the rat gut? Immunohistochemical evidence for a new type of peripheral nerves. Experientia, 1975, 31(7), 852-854.

[9] Pelletier, G.; Leclerc, R.; Arimura, A.; Schally, A. V. Letter: Immunohistochemical localization of somatostatin in the rat pancreas. J. Histochem. Cytochem., 1975, 23(9), 699-702.

[10] Patel, Y. C.; Reichlin, S. Somatostatin in hypothalamus, extrahypothalamic brain, and peripheral tissues of the rat. Endocrinology, 1978, 102(2), 523-530. 
[11] Finley, J. C.; Maderdrut, J. L.; Roger, L. J.; Petrusz, P. The immunocytochemical localization of somatostatin-containing neurons in the rat central nervous system. Neuroscience, 1981, 6(11), 2173-2192.

[12] Reichlin, S. Somatostatin. N. Engl. J. Med., 1983, 309(24), 1495-1501.

[13] Reichlin, S. Somatostatin (second of two parts). N. Engl. J. Med., 1983, 309(25), $1556-1563$.

[14] Johansson, O.; Hokfelt, T.; Elde, R. P. Immunohistochemical distribution of somatostatin-like immunoreactivity in the central nervous system of the adult rat. Neuroscience, 1984, 13(2), 265-339.

[15] Aguila, M. C.; Dees, W. L.; Haensly, W. E.; McCann, S. M. Evidence that somatostatin is localized and synthesized in lymphoid organs. Proc. Natl. Acad. Sci. U. S. A, 1991, 88(24), 11485-11489.

[16] Viollet, C.; Lepousez, G.; Loudes, C.; Videau, C.; Simon, A.; Epelbaum, J. Somatostatinergic systems in brain: networks and functions. Mol. Cell. Endocrinol., 2008, 286(1-2), 75-87.

[17] Lepousez, G.; Csaba, Z.; Bernard, V.; Loudes, C.; Videau, C.; Lacombe, J.; Epelbaum, J.; Viollet, C. Somatostatin interneurons delineate the inner part of the external plexiform layer in the mouse main olfactory bulb. J. Comp Neurol., 2010, 518(11), 1976-1994.

[18] Lepousez, G.; Mouret, A.; Loudes, C.; Epelbaum, J.; Viollet, C. Somatostatin contributes to in vivo gamma oscillation modulation and odor discrimination in the olfactory bulb. J. Neurosci., 2010, 30(3), 870-875.

[19] Epelbaum, J.; Guillou, J. L.; Gastambide, F.; Hoyer, D.; Duron, E.; Viollet, C. Somatostatin, Alzheimer's disease and cognition: an old story coming of age? Prog. Neurobiol., 2009, 89(2), 153-161. 
[20] Gonzalez, B. J.; Leroux, P.; Bodenant, C.; Laquerriere, A.; Coy, D. H.; Vaudry, H. Ontogeny of somatostatin receptors in the rat brain: biochemical and autoradiographic study. Neuroscience, 1989, 29(3), 629-644.

[21] Sirviö, J.; Jolkkonen, J.; Pitkanen, A.; Riekkinen, P. J. Age dependence of somatostatin levels and somatostatin binding in the rat brain. Comp. Biochem. Physiol. A. Comp. Physiol., 1987, 87(2), 355-357.

[22] Leroux, P.; Bodenant, C.; Bologna, E.; Gonzalez, B.; Vaudry, H. Transient expression of somatostatin receptors in the brain during development. Ciba Found. Symp., 1995, 190127-137.

[23] Yacubova, E.; Komuro, H. Stage-specific control of neuronal migration by somatostatin. Nature, 2002, 415(6867), 77-81.

[24] Stanic, D.; Malmgren, H.; He, H.; Scott, L.; Aperia, A.; Hokfelt, T. Developmental changes in frequency of the ciliary somatostatin receptor 3 protein. Brain Res., 2009, 1249101-112.

[25] Goodyer, C. G.; Grigorakis, S. I.; Patel, Y. C.; Kumar, U. Developmental changes in the expression of somatostatin receptors (1-5) in the brain, hypothalamus, pituitary and spinal cord of the human fetus. Neuroscience, 2004, 125(2), 441-448.

[26] Le, V., V; Kaindl, A. M.; Verney, C.; Csaba, Z.; Peineau, S.; Olivier, P.; AdleBiassette, H.; Leterrier, C.; Vitalis, T.; Renaud, J.; Dargent, B.; Gressens, P.; Dournaud, $\mathrm{P}$. The somatostatin $2 \mathrm{~A}$ receptor is enriched in migrating neurons during rat and human brain development and stimulates migration and axonal outgrowth. PLoS. One., 2009, $4(5)$, e5509-

[27] Rens-Domiano, S.; Reisine, T. Structural analysis and functional role of the carbohydrate component of somatostatin receptors. J. Biol. Chem., 1991, 266(30), $20094-$ 20102.

[28] Rens-Domiano, S.; Reisine, T. Biochemical and functional properties of somatostatin receptors. J. Neurochem., 1992, 58(6), 1987-1996. 
[29] Hannon, J. P.; Nunn, C.; Stolz, B.; Bruns, C.; Weckbecker, G.; Lewis, I.; Troxler, T.; Hurth, K.; Hoyer, D. Drug design at peptide receptors: somatostatin receptor ligands. $J$. Mol. Neurosci., 2002, 18(1-2), 15-27.

[30] Olias, G.; Viollet, C.; Kusserow, H.; Epelbaum, J.; Meyerhof, W. Regulation and function of somatostatin receptors. J. Neurochem., 2004, 89(5), 1057-1091.

[31] Siehler, S.; Nunn, C.; Hannon, J.; Feuerbach, D.; Hoyer, D. Pharmacological profile of somatostatin and cortistatin receptors. Mol. Cell. Endocrinol., 2008, 286(1-2), 26-34.

[32] Córdoba-Chacón, J.; Gahete, M. D.; Duran-Prado, M.; Pozo-Salas, A. I.; Malagon, M. M.; Gracia-Navarro, F.; Kineman, R. D.; Luque, R. M.; Castano, J. P. Identification and characterization of new functional truncated variants of somatostatin receptor subtype 5 in rodents. Cell. Mol. Life Sci., 2010, 67(7), 1147-1163.

[33] Reisine, T.; Bell, G. I. Molecular properties of somatostatin receptors. Neuroscience, 1995, 67(4), 777-790.

[34] Jiang, N.; Furue, H.; Katafuchi, T.; Yoshimura, M. Somatostatin directly inhibits substantia gelatinosa neurons in adult rat spinal dorsal horn in vitro. Neurosci. Res., 2003, 47(1), 97-107.

[35] Baraban, S. C.; Tallent, M. K. Interneuron Diversity series: Interneuronal neuropeptides--endogenous regulators of neuronal excitability. Trends Neurosci., 2004, 27(3), 135-142.

[36] Meis, S.; Sosulina, L.; Schulz, S.; Hollt, V.; Pape, H. C. Mechanisms of somatostatin-evoked responses in neurons of the rat lateral amygdala. Eur. J. Neurosci., 2005, 21(3), 755-762.

[37] Viana, F.; Hille, B. Modulation of high voltage-activated calcium channels by somatostatin in acutely isolated rat amygdaloid neurons. J. Neurosci., 1996, 16(19), 6000-6011. 
[38] Baraban, S. C.; Tallent, M. K. Interneuron Diversity series: Interneuronal neuropeptides--endogenous regulators of neuronal excitability. Trends Neurosci., 2004, 27(3), 135-142.

[39] Galarraga, E.; Vilchis, C.; Tkatch, T.; Salgado, H.; Tecuapetla, F.; Perez-Rosello, T.; Perez-Garci, E.; Hernandez-Echeagaray, E.; Surmeier, D. J.; Bargas, J. Somatostatinergic modulation of firing pattern and calcium-activated potassium currents in medium spiny neostriatal neurons. Neuroscience, 2007, 146(2), 537-554.

[40] Cervia, D.; Casini, G.; Bagnoli, P. Physiology and pathology of somatostatin in the mammalian retina: a current view. Mol. Cell. Endocrinol., 2008, 286(1-2), 112-122.

[41] Reisine, T. Somatostatin receptors. Am. J. Physiol, 1995, 269(6 Pt 1), G813-G820.

[42] Momiyama, T.; Zaborszky, L. Somatostatin presynaptically inhibits both GABA and glutamate release onto rat basal forebrain cholinergic neurons. J. Neurophysiol., 2006, 96(2), 686-694.

[43] Grilli, M.; Raiteri, L.; Pittaluga, A. Somatostatin inhibits glutamate release from mouse cerebrocortical nerve endings through presynaptic sst 2 receptors linked to the adenylyl cyclase-protein kinase A pathway. Neuropharmacology, 2004, 46(3), 388-396.

[44] Lanneau, C.; Peineau, S.; Petit, F.; Epelbaum, J.; Gardette, R. Somatostatin modulation of excitatory synaptic transmission between periventricular and arcuate hypothalamic nuclei in vitro. J. Neurophysiol., 2000, 84(3), 1464-1474.

[45] Nakata, A.; Saito, H.; Nishiyama, N. Facilitatory role of somatostatin via muscarinic cholinergic system in the generation of long-term potentiation in the rat dentate gyrus in vivo. Brain Res., 1996, 723(1-2), 135-140.

[46] Peineau, S.; Potier, B.; Petit, F.; Dournaud, P.; Epelbaum, J.; Gardette, R. AMPAsst2 somatostatin receptor interaction in rat hypothalamus requires activation of NMDA and/or metabotropic glutamate receptors and depends on intracellular calcium. J. Physiol, 2003, 546(Pt 1), 101-117. 
[47] Dutar, P.; Vaillend, C.; Viollet, C.; Billard, J. M.; Potier, B.; Carlo, A. S.; Ungerer, A.; Epelbaum, J. Spatial learning and synaptic hippocampal plasticity in type 2 somatostatin receptor knock-out mice. Neuroscience, 2002, 112(2), 455-466.

[48] Cammalleri, M.; Cervia, D.; Dal Monte, M.; Martini, D.; Langenegger, D.; Fehlmann, D.; Feuerbach, D.; Pavan, B.; Hoyer, D.; Bagnoli, P. Compensatory changes in the hippocampus of somatostatin knockout mice: upregulation of somatostatin receptor 2 and its function in the control of bursting activity and synaptic transmission. Eur. J. Neurosci., 2006, 23(9), 2404-2422.

[49] Moneta, D.; Richichi, C.; Aliprandi, M.; Dournaud, P.; Dutar, P.; Billard, J. M.; Carlo, A. S.; Viollet, C.; Hannon, J. P.; Fehlmann, D.; Nunn, C.; Hoyer, D.; Epelbaum, J.; Vezzani, A. Somatostatin receptor subtypes 2 and 4 affect seizure susceptibility and hippocampal excitatory neurotransmission in mice. Eur. J. Neurosci., 2002, 16(5), 843849.

[50] Leresche, N.; Asprodini, E.; Emri, Z.; Cope, D. W.; Crunelli, V. Somatostatin inhibits GABAergic transmission in the sensory thalamus via presynaptic receptors. Neuroscience, 2000, 98(3), 513-522.

[51] Epelbaum, J. Somatostatin in the central nervous system: physiology and pathological modifications. Prog. Neurobiol., 1986, 27(1), 63-100.

[52] Lanneau, C.; Bluet-Pajot, M. T.; Zizzari, P.; Csaba, Z.; Dournaud, P.; Helboe, L.; Hoyer, D.; Pellegrini, E.; Tannenbaum, G. S.; Epelbaum, J.; Gardette, R. Involvement of the Sst1 somatostatin receptor subtype in the intrahypothalamic neuronal network regulating growth hormone secretion: an in vitro and in vivo antisense study. Endocrinology, 2000, 141(3), 967-979.

[53] Zheng, H.; Bailey, A.; Jiang, M. H.; Honda, K.; Chen, H. Y.; Trumbauer, M. E.; Van der Ploeg, L. H.; Schaeffer, J. M.; Leng, G.; Smith, R. G. Somatostatin receptor subtype 2 knockout mice are refractory to growth hormone-negative feedback on arcuate neurons. Mol. Endocrinol., 1997, 11(11), 1709-1717. 
[54] Raynor, K.; Reisine, T. Somatostatin receptors. Crit. Rev. Neurobiol., 1992, 6(4), 273-289.

[55] Vécsei, L.; Widerlöv, E. Preclinical and clinical studies with somatostatin related to the central nervous system. Prog. Neuropsychopharmacol. Biol. Psychiatry, 1990, 14(4), 473-502.

[56] Siler, T. M.; VandenBerg, G.; Yen, S. S.; Brazeau, P.; Vale, W.; Guillemin, R. Inhibition of growth hormone release in humans by somatostatin. J. Clin. Endocrinol. Metab., 1973, 37(4), 632-634.

[57] Havlicek, V.; Rezek, M.; Friesen, H. Somatostatin and thyrotropin releasing hormone: central effect on sleep and motor system. Pharmacol. Biochem. Behav., 1976, $4(4), 455-459$.

[58] Vécsei, L.; Schwarzberg, H.; Telegdy, G. Comparative studies with linear and cyclic somatostatin on the self-stimulation of rats. Acta Physiol. Acad. Sci. Hung., 1982, 60(3), 165-168.

[59] Vécsei, L.; Bollók, I.; Telegdy, G. Comparative studies with cyclic and linear somatostatin on active avoidance behaviour and open-field activity in rats. Acta Physiol. Hung., 1983, 61(1-2), 43-49.

[60] Vécsei, L.; Bollók, I.; Telegdy, G. The effect of linear somatostatin on the active avoidance behaviour and open-field activity on haloperidol, phenoxybenzamine and atropine pretreated rats. Acta Physiol. Hung., 1983, 62(3-4), 205-211.

[61] Vécsei, L.; Bollók, I.; Telegdy, G. Intracerebroventricular somatostatin attenuates electroconvulsive shock-induced amnesia in rats. Peptides, 1983, 4(3), 293-295.

[62] Vécsei, L.; Schwarzberg, H.; Telegdy, G. The effect of somatostatin on selfstimulation behavior in atropine- and methysergide-pretreated rats. Eur. J. Pharmacol., 1983, 91(1), 89-93. 
[63] Vécsei, L.; Bollók, I.; Varga, J.; Penke, B.; Telegdy, G. Effect of somatostatin and its fragments on turning behaviour induced by unilateral substantia nigra lesion in the rat. Acta Physiol. Hung., 1984, 64(2), 157-162.

[64] Vécsei, L.; Bollók, I.; Varga, J.; Penke, B.; Telegdy, G. The effects of somatostatin, its fragments and an analog on electroconvulsive shock-induced amnesia in rats. Neuropeptides, 1984, 4(2), 137-143.

[65] Vécsei, L.; Király, C.; Bollók, I.; Nagy, A.; Varga, J.; Penke, B.; Telegdy, G. Comparative studies with somatostatin and cysteamine in different behavioral tests on rats. Pharmacol. Biochem. Behav., 1984, 21(6), 833-837.

[66] Vécsei, L.; Widerlöv, E. Effects of intracerebroventricularly administered somatostatin on passive avoidance, shuttle-box behaviour and open-field activity in rats. Neuropeptides, 1988, 12(4), 237-242.

[67] Vécsei, L.; Pavo, I.; Zsigo, J.; Penke, B.; Widerlov, E. Comparative studies of somatostatin-14 and some of its fragments on passive avoidance behavior, open field activity and on barrel rotation phenomenon in rats. Peptides, 1989, 10(6), 1153-1157.

[68] Vécsei, L.; Widerlöv, E.; Alling, C.; Zsigo, J.; Pavo, I.; Penke, B. Somatostatin28(15-28), but not somatostatin28(1-12), affects central monoaminergic neurotransmission in rats. Neuropeptides, 1990, 16(4), 181-186.

[69] Bakhit, C.; Swerdlow, N. Behavioral changes following central injection of cysteamine in rats. Brain Res., 1986, 365(1), 159-163.

[70] Haroutunian, V.; Mantin, R.; Campbell, G. A.; Tsuboyama, G. K.; Davis, K. L. Cysteamine-induced depletion of central somatostatin-like immunoactivity: effects on behavior, learning, memory and brain neurochemistry. Brain Res., 1987, 403(2), 234242.

[71] Schettini, G.; Florio, T.; Magri, G.; Grimaldi, M.; Meucci, O.; Landolfi, E.; Marino, A. Somatostatin and SMS 201-995 reverse the impairment of cognitive functions induced 
by cysteamine depletion of brain somatostatin. Eur. J. Pharmacol., 1988, 151(3), 399407.

[72] DeNoble, V. J.; Hepler, D. J.; Barto, R. A. Cysteamine-induced depletion of somatostatin produces differential cognitive deficits in rats. Brain Res., 1989, 482(1), 4248.

[73] Kungel, M.; Koch, M.; Friauf, E. Cysteamine impairs the development of the acoustic startle response in rats: possible role of somatostatin. Neurosci. Lett., 1996, 202(3), 181-184.

[74] Fendt, M.; Koch, M.; Schnitzler, H. U. Somatostatin in the pontine reticular formation modulates fear potentiation of the acoustic startle response: an anatomical, electrophysiological, and behavioral study. J. Neurosci., 1996, 16(9), 3097-3103.

[75] Feifel, D.; Minor, K. L. Cysteamine blocks amphetamine-induced deficits in sensorimotor gating. Pharmacol. Biochem. Behav., 1997, 58(3), 689-693.

[76] Fitzgerald, L. W.; Dokla, C. P. Morris water task impairment and hypoactivity following cysteamine-induced reductions of somatostatin-like immunoreactivity. Brain Res., 1989, 505(2), 246-250.

[77] Yamazaki, M.; Matsuoka, N.; Maeda, N.; Ohkubo, Y.; Yamaguchi, I. FK960 N-(4acetyl-1-piperazinyl)-p-fluorobenzamide monohydrate ameliorates the memory deficits in rats through a novel mechanism of action. J. Pharmacol. Exp. Ther., 1996, 279(3), 11571173.

[78] Tokita, K.; Inoue, T.; Yamazaki, S.; Wang, F.; Yamaji, T.; Matsuoka, N.; Mutoh, S. FK962, a novel enhancer of somatostatin release, exerts cognitive-enhancing actions in rats. Eur. J. Pharmacol., 2005, 527(1-3), 111-120.

[79] Guillou, J. L.; Micheau, J.; Jaffard, R. The opposite effects of cysteamine on the acquisition of two different tasks in mice are associated with bidirectional testing-induced changes in hippocampal adenylyl cyclase activity. Behav. Neurosci., 1998, 112(4), 900908. 
[80] Guillou, J. L.; Micheau, J.; Jaffard, R. Intrahippocampal injections of cysteamine improve the retention of a bar-pressing task in mice. Behav. Brain Res., 1999, 103(1), 113-117.

[81] Matsuoka, N.; Maeda, N.; Yamaguchi, I.; Satoh, M. Possible involvement of brain somatostatin in the memory formation of rats and the cognitive enhancing action of FR121196 in passive avoidance task. Brain Res., 1994, 642(1-2), 11-19.

[82] Romanova, G. A.; Karganov, M. Y.; Kadar, T.; Telegdy, G. The effects of somatostatin and somatostatin antiserum on the retention of passive avoidance behavior after neofrontal decortication in rats. Physiol. Behav., 1990, 47(5), 1035-1036.

[83] Matsuoka, N.; Aigner, T. G. FK960 [N-(4-acetyl-1-piperazinyl)-p-fluorobenzamide monohydrate], a novel potential antidementia drug, improves visual recognition memory in rhesus monkeys: comparison with physostigmine. J. Pharmacol. Exp. Ther., 1997, 280(3), 1201-1209.

[84] Tokita, K.; Yamazaki, S.; Yamazaki, M.; Matsuoka, N.; Mutoh, S. Combination of a novel antidementia drug FK960 with donepezil synergistically improves memory deficits in rats. Pharmacol. Biochem. Behav., 2002, 73(3), 511-519.

[85] Tokita, K.; Inoue, T.; Yamazaki, S.; Wang, F.; Yamaji, T.; Matsuoka, N.; Mutoh, S. FK962, a novel enhancer of somatostatin release, exerts cognitive-enhancing actions in rats. Eur. J. Pharmacol., 2005, 527(1-3), 111-120.

[86] Hoyer, D.; Lubbert, H.; Bruns, C. Molecular pharmacology of somatostatin receptors. Naunyn-Schmiedeberg's Arch. Pharmacol., 1994, 350(5), 441-453.

[87] Semenova, S.; Hoyer, D.; Geyer, M. A.; Markou, A. Somatostatin-28 modulates prepulse inhibition of the acoustic startle response, reward processes and spontaneous locomotor activity in rats. Neuropeptides, 2010, 44(5), 421-429.

[88] Gastambide, F.; Viollet, C.; Lepousez, G.; Epelbaum, J.; Guillou, J. L. Hippocampal SSTR4 somatostatin receptors control the selection of memory strategies. Psychopharmacology, 2009, 202(1-3), 153-163. 
[89] Zeyda, T.; Diehl, N.; Paylor, R.; Brennan, M. B.; Hochgeschwender, U. Impairment in motor learning of somatostatin null mutant mice. Brain Res., 2001, 906(1-2), 107-114.

[90] Dutar, P.; Vaillend, C.; Viollet, C.; Billard, J. M.; Potier, B.; Carlo, A. S.; Ungerer, A.; Epelbaum, J. Spatial learning and synaptic hippocampal plasticity in type 2 somatostatin receptor knock-out mice. Neuroscience, 2002, 112(2), 455-466.

[91] Zeyda, T.; Hochgeschwender, U. Null mutant mouse models of somatostatin and cortistatin, and their receptors. Mol. Cell. Endocrinol., 2008, 286(1-2), 18-25.

[92] Olias, G.; Viollet, C.; Kusserow, H.; Epelbaum, J.; Meyerhof, W. Regulation and function of somatostatin receptors. J. Neurochem., 2004, 89(5), 1057-1091.

[93] de Lecea, L. Cortistatin--functions in the central nervous system. Mol. Cell. Endocrinol., 2008, 286(1-2), 88-95.

[94] Einstein, E. B.; Patterson, C. A.; Hon, B. J.; Regan, K. A.; Reddi, J.; Melnikoff, D. E.; Mateer, M. J.; Schulz, S.; Johnson, B. N.; Tallent, M. K. Somatostatin signaling in neuronal cilia is critical for object recognition memory. $J$. Neurosci., 2010, 30(12), 43064314.

[95] Crusio, W. E. Flanking gene and genetic background problems in genetically manipulated mice. Biol. Psychiatry, 2004, 56(6), 381-385.

[96] Frye, M. A.; Pazzaglia, P. J.; George, M. S.; Luckenbaugh, D. A.; Vanderham, E.; Davis, C. L.; Rubinow, D. R.; Post, R. M. Low CSF somatostatin associated with response to nimodipine in patents with affective illness. Biol. Psychiatry, 2003, 53(2), 180-183.

[97] Braak, H.; Braak, E. Demonstration of amyloid deposits and neurofibrillary changes in whole brain sections. Brain Pathol., 1991, 1(3), 213-216.

[98] Selkoe, D. J. Alzheimer's disease results from the cerebral accumulation and cytotoxicity of amyloid beta-protein. J. Alzheimers Dis., 2001, 3(1), 75-80. 
[99] Hsiao, K.; Chapman, P.; Nilsen, S.; Eckman, C.; Harigaya, Y.; Younkin, S.; Yang, F.; Cole, G. Correlative memory deficits, Abeta elevation, and amyloid plaques in transgenic mice. Science, 1996, 274(5284), 99-102.

[100] Selkoe, D. J. Alzheimer's disease: genes, proteins, and therapy. Physiol. Rev., 2001, 81(2), 741-766.

[101] Hardy, J. A.; Higgins, G. A. Alzheimer's disease: the amyloid cascade hypothesis. Science, 1992, 256(5054), 184-185.

[102] Selkoe, D. J. Amyloid beta-protein and the genetics of Alzheimer's disease. J. Biol. Chem., 1996, 271(31), 18295-18298.

[103] Scheuner, D.; Eckman, C.; Jensen, M.; Song, X.; Citron, M.; Suzuki, N.; Bird, T. D.; Hardy, J.; Hutton, M.; Kukull, W.; Larson, E.; Levy-Lahad, E.; Viitanen, M.; Peskind, E.; Poorkaj, P.; Schellenberg, G.; Tanzi, R.; Wasco, W.; Lannfelt, L.; Selkoe, D.; Younkin, S. Secreted amyloid beta-protein similar to that in the senile plaques of Alzheimer's disease is increased in vivo by the presenilin 1 and 2 and APP mutations linked to familial Alzheimer's disease. Nat. Med., 1996, 2(8), 864-870.

[104] Weiner, M. F.; Svetlik, D.; Risser, R. C. What depressive symptoms are reported in Alzheimer's patients? Int. J. Geriatr. Psychiatry, 1997, 12(6), 648-652.

[105] Davies, P.; Katzman, R.; Terry, R. D. Reduced somatostatin-like immunoreactivity in cerebral cortex from cases of Alzheimer disease and Alzheimer senile dementa. Nature, 1980, 288(5788), 279-280.

[106] Beal, M. F.; Benoit, R.; Mazurek, M. F.; Bird, E. D.; Martin, J. B. Somatostatin28(1-12)-like immunoreactivity is reduced in Alzheimer's disease cerebral cortex. Brain Res., 1986, 368(2), 380-383.

[107] Davis, K. L.; Davidson, M.; Yang, R. K.; Davis, B. M.; Siever, L. J.; Mohs, R. C.; Ryan, T.; Coccaro, E.; Bierer, L.; Targum, S. D. CSF somatostatin in Alzheimer's disease, depressed patients, and control subjects. Biol. Psychiatry, 1988, 24(6), 710-712. 
[108] Bissette, G.; Myers, B. Somatostatin in Alzheimer's disease and depression. Life Sci., 1992, 51(18), 1389-1410.

[109] Nemeroff, C. B.; Knight, D. L.; Bissette, G. Somatostatin: a neuropeptide system pathologically altered in Alzheimer's disease and depression. Clin. Neuropharmacol., 1992, 15 Suppl 1 Pt A311A-312A.

[110] Molchan, S. E.; Hill, J. L.; Martinez, R. A.; Lawlor, B. A.; Mellow, A. M.; Rubinow, D. R.; Bissette, G.; Nemeroff, C. B.; Sunderland, T. CSF somatostatin in Alzheimer's disease and major depression: relationship to hypothalamic-pituitary-adrenal axis and clinical measures. Psychoneuroendocrinology, 1993, 18(7), 509-519.

[111] Bissette, G.; Cook, L.; Smith, W.; Dole, K. C.; Crain, B.; Nemeroff, C. B. Regional Neuropeptide Pathology in Alzheimer's Disease: Corticotropin-Releasing Factor and Somatostatin. J. Alzheimers Dis., 1998, 1(2), 91-105.

[112] Nilsson, C. L.; Brinkmalm, A.; Minthon, L.; Blennow, K.; Ekman, R. Processing of neuropeptide $\mathrm{Y}$, galanin, and somatostatin in the cerebrospinal fluid of patients with Alzheimer's disease and frontotemporal dementia. Peptides, 2001, 22(12), 2105-2112.

[113] Kumar, U. Expression of somatostatin receptor subtypes (SSTR1-5) in Alzheimer's disease brain: an immunohistochemical analysis. Neuroscience, 2005, 134(2), 525-538.

[114] Dournaud, P.; Delaere, P.; Hauw, J. J.; Epelbaum, J. Differential correlation between neurochemical deficits, neuropathology, and cognitive status in Alzheimer's disease. Neurobiol. Aging, 1995, 16(5), 817-823.

[115] Ramos, B.; Baglietto-Vargas, D.; del Rio, J. C.; Moreno-Gonzalez, I.; Santa-Maria, C.; Jimenez, S.; Caballero, C.; Lopez-Tellez, J. F.; Khan, Z. U.; Ruano, D.; Gutierrez, A.; Vitorica, J. Early neuropathology of somatostatin/NPY GABAergic cells in the hippocampus of a PS1xAPP transgenic model of Alzheimer's disease. Neurobiol. Aging, 2006, 27(11), 1658-1672. 
[116] Saito, T.; Iwata, N.; Tsubuki, S.; Takaki, Y.; Takano, J.; Huang, S. M.; Suemoto, T.; Higuchi, M.; Saido, T. C. Somatostatin regulates brain amyloid beta peptide Abeta42 through modulation of proteolytic degradation. Nat. Med., 2005, 11(4), 434-439.

[117] Nag, S.; Yee, B. K.; Tang, F. Reduction in somatostatin and substance P levels and choline acetyltransferase activity in the cortex and hippocampus of the rat after chronic intracerebroventricular infusion of beta-amyloid (1-40). Brain Res. Bull., 1999, 50(4), 251-262.

[118] Hervas-Aguilar, A.; Puebla-Jimenez, L.; Burgos-Ramos, E.; Aguado-Llera, D.; Arilla-Ferreiro, E. Effects of single and continuous administration of amyloid betapeptide (25-35) on adenylyl cyclase activity and the somatostatinergic system in the rat frontal and parietal cortex. Neuroscience, 2005, 135(1), 181-190.

[119] Aguado-Llera, D.; Arilla-Ferreiro, E.; Campos-Barros, A.; Puebla-Jimenez, L.; Barrios, V. Protective effects of insulin-like growth factor-I on the somatostatinergic system in the temporal cortex of beta-amyloid-treated rats. J. Neurochem., 2005, 92(3), 607-615.

[120] Burgos-Ramos, E.; Hervas-Aguilar, A.; Puebla-Jimenez, L.; Boyano-Adanez, M. C.; Arilla-Ferreiro, E. Chronic but not acute intracerebroventricular administration of amyloid beta-peptide(25-35) decreases somatostatin content, adenylate cyclase activity, somatostatin-induced inhibition of adenylate cyclase activity, and adenylate cyclase I levels in the rat hippocampus. J. Neurosci. Res., 2007, 85(2), 433-442.

[121] Aguado-Llera, D.; Arilla-Ferreiro, E.; Chowen, J. A.; Argente, J.; Puebla-Jimenez, L.; Frago, L. M.; Barrios, V. 17Beta-estradiol protects depletion of rat temporal cortex somatostatinergic system by beta-amyloid. Neurobiol. Aging, 2007, 28(9), 1396-1409.

[122] Beal, M. F.; Mazurek, M. F.; Tran, V. T.; Chattha, G.; Bird, E. D.; Martin, J. B. Reduced numbers of somatostatin receptors in the cerebral cortex in Alzheimer's disease. Science, 1985, 229(4710), 289-291. 
[123] Whitford, C.; Candy, J.; Edwardson, J.; Perry, R. Cortical somatostatinergic system not affected in Alzheimer's and Parkinson's diseases. J. Neurol. Sci., 1988, 86(1), 13-18.

[124] Krantic, S.; Robitaille, Y.; Quirion, R. Deficits in the somatostatin SS1 receptor sub-type in frontal and temporal cortices in Alzheimer's disease. Brain Res., 1992, 573(2), 299-304.

[125] A novel gene containing a trinucleotide repeat that is expanded and unstable on Huntington's disease chromosomes. The Huntington's Disease Collaborative Research Group. Cell, 1993, 72(6), 971-983.

[126] Cooper, J. K.; Schilling, G.; Peters, M. F.; Herring, W. J.; Sharp, A. H.; Kaminsky, Z.; Masone, J.; Khan, F. A.; Delanoy, M.; Borchelt, D. R.; Dawson, V. L.; Dawson, T. M.; Ross, C. A. Truncated N-terminal fragments of huntingtin with expanded glutamine repeats form nuclear and cytoplasmic aggregates in cell culture. Hum. Mol. Genet., 1998, 7(5), 783-790.

[127] Hahn-Barma, V.; Deweer, B.; Durr, A.; Dode, C.; Feingold, J.; Pillon, B.; Agid, Y.; Brice, A.; Dubois, B. Are cognitive changes the first symptoms of Huntington's disease? A study of gene carriers. J. Neurol. Neurosurg. Psychiatry, 1998, 64(2), 172-177.

[128] Lawrence, A. D.; Hodges, J. R.; Rosser, A. E.; Kershaw, A.; ffrench-Constant, C.; Rubinsztein, D. C.; Robbins, T. W.; Sahakian, B. J. Evidence for specific cognitive deficits in preclinical Huntington's disease. Brain, 1998, 121(7), 1329-1341.

[129] Snowden, J. S.; Craufurd, D.; Thompson, J.; Neary, D. Psychomotor, executive, and memory function in preclinical Huntington's disease. J. Clin. Exp. Neuropsychol., 2002, 24(2), 133-145.

[130] Van Raamsdonk, J. M.; Pearson, J.; Slow, E. J.; Hossain, S. M.; Leavitt, B. R.; Hayden, M. R. Cognitive dysfunction precedes neuropathology and motor abnormalities in the YAC128 mouse model of Huntington's disease. J. Neurosci., 2005, 25(16), 41694180 . 
[131] Cramer, H.; Kohler, J.; Oepen, G.; Schomburg, G.; Schroter, E. Huntington's chorea-- measurements of somatostatin, substance $\mathrm{P}$ and cyclic nucleotides in the cerebrospinal fluid. J. Neurol., 1981, 225(3), 183-187.

[132] Aronin, N.; Cooper, P. E.; Lorenz, L. J.; Bird, E. D.; Sagar, S. M.; Leeman, S. E.; Martin, J. B. Somatostatin is increased in the basal ganglia in Huntington disease. Ann. Neurol., 1983, 13(5), 519-526.

[133] Nemeroff, C. B.; Youngblood, W. W.; Manberg, P. J.; Prange, A. J., Jr.; Kizer, J. S. Regional brain concentrations of neuropeptides in Huntington's chorea and schizophrenia. Science, 1983, 221(4614), 972-975.

[134] Beal, M. F.; Bird, E. D.; Langlais, P. J.; Martin, J. B. Somatostatin is increased in the nucleus accumbens in Huntington's disease. Neurology, 1984, 34(5), 663-666.

[135] Manberg, P. J.; Nemeroff, C. B.; Bissette, G.; Widerlov, E.; Youngblood, W. W.; Kizer, J. S.; Prange, A. J., Jr. Neuropeptides in CSF and post-mortem brain tissue of normal controls, schizophrenics and Huntington's choreics. Prog. Neuropsychopharmacol. Biol. Psychiatry, 1985, 9(1), 97-108.

[136] Marshall, P. E.; Landis, D. M. Huntington's disease is accompanied by changes in the distribution of somatostatin-containing neuronal processes. Brain Res., 1985, 329(12), 71-82.

[137] Coyle, J. T.; Schwarcz, R. Lesion of striatal neurones with kainic acid provides a model for Huntington's chorea. Nature, 1976, 263(5574), 244-246.

[138] Beal, M. F.; Kowall, N. W.; Ellison, D. W.; Mazurek, M. F.; Swartz, K. J.; Martin, J. B. Replication of the neurochemical characteristics of Huntington's disease by quinolinic acid. Nature, 1986, 321(6066), 168-171.

[139] Beal, M. F.; Ferrante, R. J.; Swartz, K. J.; Kowall, N. W. Chronic quinolinic acid lesions in rats closely resemble Huntington's disease. J. Neurosci., 1991, 11(6), 16491659. 
[140] Vécsei, L.; Beal, M. F. Comparative behavioral and neurochemical studies with striatal kainic acid- or quinolinic acid-lesioned rats. Pharmacol. Biochem. Behav., 1991, $39(2), 473-478$.

[141] Palacios, J. M.; Rigo, M.; Chinaglia, G.; Probst, A. Reduced density of striatal somatostatin receptors in Huntington's chorea. Brain Res., 1990, 522(2), 342-346.

[142] Shults, C.; Steardo, L.; Barone, P.; Mohr, E.; Juncos, J.; Serrati, C.; Fedio, P.; Tamminga, C. A.; Chase, T. N. Huntington's disease: effect of cysteamine, a somatostatin-depleting agent. Neurology, 1986, 36(8), 1099-1102.

[143] Van Raamsdonk, J. M.; Pearson, J.; Bailey, C. D.; Rogers, D. A.; Johnson, G. V.; Hayden, M. R.; Leavitt, B. R. Cystamine treatment is neuroprotective in the YAC128 mouse model of Huntington disease. J. Neurochem., 2005, 95(1), 210-220.

[144] Dupont, E.; Christensen, S. E.; Hansen, A. P.; de Fine, O. B.; Orskov, H. Low cerebrospinal fluid somatostatin in Parkinson disease: an irreversible abnormality. Neurology, 1982, 32(3), 312-314.

[145] Epelbaum, J.; Ruberg, M.; Moyse, E.; Javoy-Agid, F.; Dubois, B.; Agid, Y. Somatostatin and dementia in Parkinson's disease. Brain Res., 1983, 278(1-2), 376-379.

[146] Cramer, H.; Wolf, A.; Rissler, K.; Weigel, K.; Ostertag, C. Ventricular somatostatin-like immunoreactivity in patients with basal ganglia disease. J. Neurol., 1985, 232(4), 219-222.

[147] Beal, M. F.; Mazurek, M. F.; Martin, J. B. Somatostatin immunoreactivity is reduced in Parkinson's disease dementia with Alzheimer's changes. Brain Res., 1986, 397(2), 386-388.

[148] Strittmatter, M. M.; Cramer, H. Parkinson's disease and dementia: clinical and neurochemical correlations. Neuroreport, 1992, 3(5), 413-416.

[149] Strittmatter, M.; Hamann, G. F.; Strubel, D.; Cramer, H.; Schimrigk, K. Somatostatin-like immunoreactivity, its molecular forms and monoaminergic metabolites 
in aged and demented patients with Parkinson's disease--effect of L-Dopa. J. Neural Transm., 1996, 103(5), 591-602.

[150] Eve, D. J.; Nisbet, A. P.; Kingsbury, A. E.; Temlett, J.; Marsden, C. D.; Foster, O. J. Selective increase in somatostatin mRNA expression in human basal ganglia in Parkinson's disease. Brain Res. Mol. Brain Res., 1997, 50(1-2), 59-70.

[151] Espino, A.; Calopa, M.; Ambrosio, S.; Ortola, J.; Peres, J.; Navarro, M. A. CSF somatostatin increase in patients with early parkinsonian syndrome. J. Neural Transm. Park. Dis. Dement. Sect., 1995, 9(2-3), 189-196.

[152] Arai, H.; Moroji, T.; Kosaka, K. Somatostatin and vasoactive intestinal polypeptide in postmortem brains from patients with Alzheimer-type dementia. Neurosci. Lett., 1984, 52(1-2), 73-78.

[153] Candy, J. M.; Gascoigne, A. D.; Biggins, J. A.; Smith, A. I.; Perry, R. H.; Perry, E. K.; McDermott, J. R.; Edwardson, J. A. Somatostatin immunoreactivity in cortical and some subcortical regions in Alzheimer's disease. J. Neurol. Sci., 1985, 71(2-3), 315-323.

[154] Francis, P. T.; Bowen, D. M.; Lowe, S. L.; Neary, D.; Mann, D. M.; Snowden, J. S. Somatostatin content and release measured in cerebral biopsies from demented patients. J. Neurol. Sci., 1987, 78(1), 1-16.

[155] Whitford, C.; Candy, J.; Edwardson, J.; Perry, R. Cortical somatostatinergic system not affected in Alzheimer's and Parkinson's diseases. J. Neurol. Sci., 1988, 86(1), 13-18.

[156] Poewe, W.; Benke, T.; Karamat, E.; Schelosky, L.; Wagner, M.; Sperk, G. CSF somatostatin-like immunoreactivity in dementia of Parkinson's disease. J. Neurol. Neurosurg. Psychiatry, 1990, 53(12), 1105-1106.

[157] Nilsson, A.; Falth, M.; Zhang, X.; Kultima, K.; Skold, K.; Svenningsson, P.; Andren, P. E. Striatal alterations of secretogranin-1, somatostatin, prodynorphin, and cholecystokinin peptides in an experimental mouse model of Parkinson disease. Mol. Cell. Proteomics, 2009, 8(5), 1094-1104. 
[158] Shiraishi, M.; Kobayashi, T.; Watanabe, H.; Kamo, T.; Hasegawa, Y. Serum somatostatin in early-stage Parkinson's disease. Acta Neurol. Scand., 2010, 121(4), 225229.

[159] Cotzias, G. C.; Papavasiliou, P. S.; Ginos, J. Z. Therapeutic approaches in Parkinson's disease: possible roles of growth hormone and somatostatin. Res. Publ. Assoc. Res. Nerv. Ment. Dis., 1976, 55305-315.

[160] Dupont, E.; Hansen, A. P.; Juul-Jensen, P.; Lundbaek, K.; Magnussen, I.; de Fine, O. B. Somatostatin in the treatment of patients with extra-pyramidal disorders and patients with EEG abnormalities. Acta Neurol. Scand., 1978, 57(6), 488-493.

[161] Raaphorst, J.; de Visser, M.; Linssen, W. H.; de Haan, R. J.; Schmand, B. The cognitive profile of amyotrophic lateral sclerosis: A meta-analysis. Amyotroph. Lateral. Scler., 2010, 11(1-2), 27-37.

[162] Ringholz, G. M.; Appel, S. H.; Bradshaw, M.; Cooke, N. A.; Mosnik, D. M.; Schulz, P. E. Prevalence and patterns of cognitive impairment in sporadic ALS. Neurology, 2005, 65(4), 586-590.

[163] Rusina, R.; Ridzon, P.; Kulist'ak, P.; Keller, O.; Bartos, A.; Buncova, M.; Fialova, L.; Koukolik, F.; Matej, R. Relationship between ALS and the degree of cognitive impairment, markers of neurodegeneration and predictors for poor outcome. A prospective study. Eur. J. Neurol., 2010, 17(1), 23-30.

[164] Frank, B.; Haas, J.; Heinze, H. J.; Stark, E.; Munte, T. F. Relation of neuropsychological and magnetic resonance findings in amyotrophic lateral sclerosis: evidence for subgroups. Clin. Neurol. Neurosurg., 1997, 99(2), 79-86.

[165] Pinkhardt, E. H.; van Elst, L. T.; Ludolph, A. C.; Kassubek, J. Amygdala size in amyotrophic lateral sclerosis without dementia: an in vivo study using MRI volumetry. BMC. Neurol., 2006, 648-

[166] Desai, J.; Swash, M. Extrapyramidal involvement in amyotrophic lateral sclerosis: backward falls and retropulsion. J. Neurol. Neurosurg. Psychiatry, 1999, 67(2), 214-216. 
[167] Katagiri, T.; Kuzirai, T.; Nihei, K.; Honda, K.; Sasaki, H.; Polak, J. M. Immunocytochemical study of Onuf's nucleus in amyotrophic lateral sclerosis. Jpn. J. Med., 1988, 27(1), 23-28.

[168] Hartikainen, P.; Reinikainen, K. J.; Soininen, H.; Sirvio, J.; Soikkeli, R.; Riekkinen, P. J. Neurochemical markers in the cerebrospinal fluid of patients with Alzheimer's disease, Parkinson's disease and amyotrophic lateral sclerosis and normal controls. $J$. Neural Transm. Park. Dis. Dement. Sect., 1992, 4(1), 53-68.

[169] Nieto-Gonzalez, J. L.; Moser, J.; Lauritzen, M.; Schmitt-John, T.; Jensen, K. Reduced GABAergic inhibition explains cortical hyperexcitability in the wobbler mouse model of ALS. Cereb. Cortex, 2011, 21(3), 625-635. 